\title{
Nitric oxide enhancement and blood pressure decrease in patients with metabolic syndrome using soy protein or fish oil
}

\author{
Aumento de óxido nítrico e diminuição da pressão \\ sanguínea em pacientes com síndrome metabólica \\ em uso de proteína de soja ou óleo de peixe
}

Andréa Name Colado Simão', Marcell Alysson Batisti Lozovoy², Tathiana Name Colado Simão ${ }^{3}$, Jane Bandeira Dichi', Tiemi Matsuo5, Isaias $\mathrm{Dichi}^{4}$

1 Departamento de Patologia, Análises Clínicas e Toxocologia, Universidade Estadual de Londrina (UEL), Londrina, PR, Brazil ${ }^{2}$ Departamento de Análises Clínicas, Universidade Norte do Paraná (Unopar), Londrina, PR, Brazil ${ }^{3}$ Departamento de Nutrição Clínica, Unopar, Londrina, PR, Brazil ${ }^{4}$ Departamento de Medicina Interna, UEL, Londrina, PR, Brazil ${ }^{5}$ Departamento de Estatística, UEL, Londrina, PR, Brazil

\section{Correspondence to:}

Isaias Dichi

Departamento de Medicina Interna Rua Robert Koch, 60

Universidade Estadual de Londrina 86038-440 - Londrina, PR, Brazil dichi@sercomtel.com.br

Received on May/10/2010 Accepted on July/10/2010

\begin{abstract}
Objective: To verify the effects of fish oil and soy on nitric oxide (NO) and blood pressure in patients with metabolic syndrome (MS). Subjects and methods: Sixty women with MS were investigated in a parallel randomized design study. The first group maintained their usual diet; the second group received $25 \mathrm{~g} /$ day of soy; the third group received $3 \mathrm{~g} /$ day of $n-3$ fatty acids, and the fourth group the same amount previously cited of $n-3$ fatty acids and soy. Results: Serum nitric oxide metabolites showed significant increase after 90 days in the fish oil and soy groups. Systolic pressure reduced after 45 days of treatment with fish oil, whereas diastolic pressure decreased significantly throughout the study in the soy group. Conclusions: NO increase and blood pressure reduction with fish oil or soy protein reinforce the importance of the influence of NO on blood pressure in patients with MS. Arq Bras Endocrinol Metab. 2010;54(6):540-5
\end{abstract}

\section{Keywords}

Metabolic syndrome; soy; fish oil; blood pressure; nitric oxide

\section{RESUMO}

Objetivo: Verificar o efeito do óleo de peixe e soja sobre o óxido nítrico (NO) e a pressão arterial em pacientes com síndrome metabólica (SM). Sujeitos e métodos: Sessenta mulheres com SM foram avaliadas em estudo paralelo randomizado. 0 primeiro grupo manteve sua dieta habitual, o segundo grupo recebeu $25 \mathrm{~g} /$ dia de soja, o terceiro grupo recebeu $3 \mathrm{~g} / \mathrm{dia}$ de ácidos graxos n-3 e o quarto grupo, a mesma quantidade citada anteriormente de ácidos graxos n-3 e soja. Resultados: Os níveis séricos de metabólitos de NO foram significativamente superiores após 90 dias de intervenção com soja ou óleo de peixe. Somente o grupo que recebeu o óleo de peixe apresentou redução na pressão sistólica após 45 dias. Já a soja reduziu a pressão diastólica em 45 e 90 dias. Conclusões: $\mathrm{O}$ aumento de $\mathrm{NO}$ e a redução da pressão arterial com óleo de peixe ou proteína de soja reforçam a influência do óxido nítrico sobre a pressão arterial em pacientes com SM. Arq Bras Endocrinol Metab. 2010;54(6):540-5

Descritores

Síndrome metabólica; soja; óleo de peixe; pressão arterial; óxido nítrico

\section{INTRODUCTION}

$\mathrm{M}$ etabolic syndrome (MS) comprises pathological conditions that include insulin resistance, arterial hypertension, visceral adiposity and dyslipidemia, which favors the development of cardiovascular diseases (1). Existing evidence suggests that MS is rising in developed countries (2). Some studies performed in Brazil have demonstrated high prevalence in the 
cities of Vitória, Espírito Santo (30\%), Salvador, Bahia (19\%), Campos, Rio de Janeiro (18\%), and also in Cavunge $(24.8 \%)$, a semi-arid rural district in Bahia (3-6).

Research studies examining food groups are important and there is a trend in the literature to verify the relation between dietary patterns and cardiovascular risk factors (7). However, studies examining single nutrients such as fish- and soy-based products are also warranted to enhance the understanding of the mechanisms by which they may be protective.

Currently, many factors are considered involved in the beneficial cardiovascular effects of fish oil n-3 fatty acids (8-10) and soy products (11-13), including reduced blood pressure $(14,15)$. Evidence suggests that nitric oxide (NO) plays a major role in regulating blood pressure and that impaired NO bioactivity is an important component of hypertension (16) Furthermore, increase in NO has been reported as one of the pathophysiological mechanisms implicated in reducing blood pressure using fish oil n-3 fatty acids $(14,17)$ or soy products (15).

Although endothelial dysfunction has been considered an important issue in patients with MS, the results of studies on serum NO metabolite levels in patients with MS have been contradictory $(18,19)$. Sun and cols. (18) showed that NO metabolite levels were reduced in MS. However, Asl and cols. (19) showed higher NO metabolite concentration in subjects with MS and type 2 diabetes.

Thus, the present study reports the effects of fish oil and soy protein enriched with isoflavones on NO bioavailability and blood pressure measurements in patients with MS.

\section{SUBJECTS AND METHODS}

\section{Subjects}

Sixty of the 100 screened women with MS who fulfilled the entry criteria were selected among ambulatory patients of the University Hospital of Londrina, Paraná, Brazil. The patients were instructed not to change their usual diets, alcohol intake, level of physical activity, or other lifestyle factors throughout the intervention period. All patients gave written informed consent, and the study protocol was fully approved (CEP 298/05) by the Ethical Committee of the University of Londrina (Paraná, Brazil).

\section{Study design}

Before the interventional study, there systolic and diastolic blood pressure were assessed, and NO metabolite levels in 60 women with metabolic syndrome and 50 healthy women paired by age and race, and with BMI between 20 and $24.9 \mathrm{~kg} / \mathrm{m}^{2}$.

Patients were randomly assigned to one of four groups, after stratification by age and body mass index (BMI). All groups were instructed to follow their usual diet. The first group only followed its usual diet (control group, $\mathrm{n}=15$ ); the second group (soy group, $\mathrm{n}=$ 15) received $25 \mathrm{~g} /$ day of kinako (toasted ground soy bean, with $12.95 \mathrm{mg}$ of soy protein and $50 \mathrm{mg}$ of isoflavones) for lunch and dinner; the third group (fish oil group, $n=15$ ) received $3 \mathrm{~g} /$ day of fish oil $\mathrm{n}-3$ fatty acids ( 10 capsules of fish oil), and the fourth group received $3 \mathrm{~g} /$ day of fish oil n-3 fatty acids and $25 \mathrm{~g}$ /day of kinako. Each fish oil capsule contained $180 \mathrm{mg}$ of eicosapentaenoic acid (EPA) and $120 \mathrm{mg}$ of docosahexaenoic acid (DHA). All the groups were evaluated on three occasions by a blind assessor: at baseline and after 45 and 90 days. Blood samples were collected within a limit of one week from the stipulated day. The soy protein enriched with isoflavone was provided by Good Soy, Uberaba, Minas Gerais, Brazil, and its quality is certified by the Brazilian Farming Research Company (EMBRAPA-SOJA, Londrina, Paraná, Brazil). The nutrient composition of the soy protein consumed by the study participants is shown in table 1 .

Table 1. Nutrient composition of Kinako

\begin{tabular}{lc}
\hline Components & Amounts are per 25 g \\
\hline Calories & 94 kcal \\
Protein (g) & 12.95 \\
Carbohydrate (g) & 6.35 \\
Lipids (g) & 5.75 \\
Fiber (g) & 3.95 \\
Calcium (mg) & 83.25 \\
Iron (mg) & 2.75 \\
Vitamin A (mcg) & 3.5 \\
Vitamin B1 (mg) & 0.23 \\
Vitamin B2 (mg) & 0.075 \\
Niacin (mg) & 0.61 \\
Isoflavones (mg) & 50 \\
\hline
\end{tabular}

MS was defined following the Adult Treatment Panel III criteria. When three out of five of the listed characteristics were verified, a diagnosis of MS was performed: 1) Abdominal obesity: waist circumference $\geq 102 \mathrm{~cm}$ 
in men and $\geq 88 \mathrm{~cm}$ in women; 2) Hypertriglyceridemia $\geq 150 \mathrm{mg} / \mathrm{dL}$ (1.695 mmol/L); 3) Low levels of HDL cholesterol: $\leq 40 \mathrm{mg} / \mathrm{dL}(1.036 \mathrm{mmol} / \mathrm{L})$ in men and $\leq 50 \mathrm{mg} / \mathrm{dL}(1.295 \mathrm{mmol} / \mathrm{L})$ in women; 4$)$ High blood pressure: $\geq 130 / 85 \mathrm{mmHg}$; 5 ) High fasting glucose: $\geq 110 \mathrm{mg} / \mathrm{dL}(6.1 \mathrm{mmol} / \mathrm{L})(20)$.

None of the participants of the study presented thyroid, renal, hepatic, gastrointestinal, or oncology disease or were receiving lipid-lowering drugs, estrogen replacement therapy, or drugs for hyperglycemia. No patient was taking fish oil or soy supplements before the study. Patients who were taking antihypertensive drugs were not excluded, but were allowed to continue taking the same dose. None of the subjects were on a specific diet.

\section{Steps taken to optimize compliance}

Various measures were taken to optimize and assess compliance $(21,22)$. Before trial entry we made sure that each patient understood that they could be allocated to any group. Boxes of fish oil capsules were handed out at the entry interview and all 2 later visits; the subjects were asked to return the boxes each time so that the number of capsules taken could be estimated by questioning the patients and counting the remaining capsules. Soy protein compliance was measured by questioning the patients and counting soy packages when patients returned to their clinical and nutritional evaluation.

\section{Anthropometric and blood pressure measurements}

Anthropometric measurements were evaluated by a blind assessor at baseline and after 45 and 90 days. Body weight was measured to the nearest $0.1 \mathrm{~kg}$ by using an electronic scale, with individuals wearing light clothing, but no shoes, in the morning; height was measured to the nearest $0.1 \mathrm{~cm}$ by using a stadiometer. Body mass index (BMI) was calculated as weight $(\mathrm{kg})$ divided by height $(\mathrm{m})$ squared. Waist circumference (WC) was measured with a soft tape on standing subjects midway between the lowest rib and the iliac crest. Waist-to-hip ratio was calculated as the body circumference midway between the inferior border of the rib cage and the superior border of the iliac crest, divided by the maximal body circumference of the buttocks. Three blood pressure measurements taken with a one minute interval between them after the subject had been sitting were recorded. The mean of these measurements was used in the analysis (23). We considered the current use of antihypertensive medication an indication of high blood pressure.

\section{Nitric oxide (NO) metabolite measurements}

Serum NO levels were assessed by nitrite $\left(\mathrm{NO}_{2}^{-}\right)$and nitrate $\left(\mathrm{NO}_{3}{ }^{-}\right)$concentration according to the Griess reaction supplemented with the reduction of nitrate to nitrite with cadmium $(24,25)$.

\section{Statistical analysis}

Mann-Whitney non-parametric test was performed to compare healthy women and MS patients. Some continuous data were transformed into more normally distributed variables by using a natural logarithm transformation. Multivariate analysis of variance (MANOVA) was employed to examine differences between the groups and the times. Multivariate analyses were followed by post hoc multiple comparisons testing with Scheffé difference test. Mean scores by group, univariate $\mathrm{F}$ statistics, significance levels, and significant post hoc comparisons are displayed in the tables. $\mathrm{P}<$ 0.05 was considered statistically significant. Values are presented as mean \pm standard deviation.

\section{RESULTS}

MS patients presented higher systolic and diastolic blood pressure and lower $\mathrm{NO}$ metabolite levels when compared to healthy controls (Table 2).

Table 2. Clinical and laboratorial characteristics of the patients with metabolic syndrome and healthy controls

\begin{tabular}{lccc}
\hline & $\begin{array}{c}\text { Controls } \\
(\mathbf{n}=\mathbf{5 0})\end{array}$ & $\begin{array}{c}\text { Metabolic } \\
\text { syndrome } \\
(\mathbf{n = 6 0}\end{array}$ & p value \\
\hline Age (years) & $42.0(8.4)$ & $45.9(9.8)$ & 0.119 \\
$\mathrm{BMI}\left(\mathrm{kg} / \mathrm{m}^{2}\right)$ & $22.9(18.7-24.9)$ & $37.2(27.1-53.9)$ & $<0.0001$ \\
$\mathrm{SBP}(\mathrm{mmHg})$ & $101.0(81.0-130.0)$ & $134.5(89.0-203.0)$ & $<0.0001$ \\
$\mathrm{DBP}(\mathrm{mmHg})$ & $65.0(47.0-80.0)$ & $83.0(53.0-124.0)$ & $<0.0001$ \\
$\mathrm{NO}(\mathrm{ug} / \mathrm{mL})$ & $6.72(5.14-12.43)$ & $5.69(2.36-8.18)$ & 0.048 \\
\hline
\end{tabular}

Mann-Whitney test. Data are median ( $\min -\max )$.

BMI: body mass index; SBP: systolic blood pressure; DBP: diastolic blood pressure; NO: nitric oxide.

Patients who followed the fish oil and soy treatments had no complaints, and according to self-report, the subject's lifestyle was unchanged throughout the study. Subjects in all groups did not drink alcohol regularly (data not shown). There were no differences between groups in respect to age and smoking status (Table 3). For ethical reasons, we could not ask the patients to stop using antihypertensive medication to participate in the study, but there was no statistically significant difference between the groups when they were compared (Table 3). 
Table 3. Clinical characteristics of the 60 metabolic syndrome patients

\begin{tabular}{lccccc}
\hline Parameters & $\begin{array}{c}\text { Control } \\
(\mathbf{n = 1 5 )}\end{array}$ & $\begin{array}{c}\text { Soy } \\
(\mathbf{n = 1 5})\end{array}$ & $\begin{array}{c}\text { Fish 0il } \\
(\mathbf{n = 1 5 )}\end{array}$ & $\begin{array}{c}\text { Soy + } \\
\text { Fish 0il } \\
(\mathbf{n = 1 5 )}\end{array}$ & $\mathbf{p}$ \\
\hline Age & $47.1(8.8)$ & $49.9(11.2)$ & $47.8(9.4)$ & $46.8(10.5)$ & 0.20 \\
Smoking & 0 & 1 & 1 & 0 & 0.57 \\
ACE & 8 & 10 & 7 & 6 & 0.51 \\
$\beta$ blockers & 1 & 2 & 4 & 3 & 0.34 \\
Diuretics & 5 & 7 & 4 & 2 & 0.26 \\
CCB & 2 & 1 & 0 & 1 & 0.55 \\
\hline
\end{tabular}

FO: fish oil; ACE: angiotensin-converting enzyme; CCB: calcium channel blockers Data are presented as mean $\pm S D$ or number of subjects.

The parameters related to body composition (BMI, WC, waist-to-hip ratio) showed no statistically significant results after 45 and 90 days in relation to the baseline values in all groups (Table 3 ). However, both systolic and diastolic blood pressure showed decreased values in some groups in relation to baseline values. Systolic pressure showed reduced values $(\mathrm{p}<0.05)$ after 45 days of treatment with fish oil, but not after 90 days. Meanwhile, diastolic pressure decreased significantly $(\mathrm{p}<0.05)$ after 45 and 90 days in the soy group as well as after 90 days in the control group

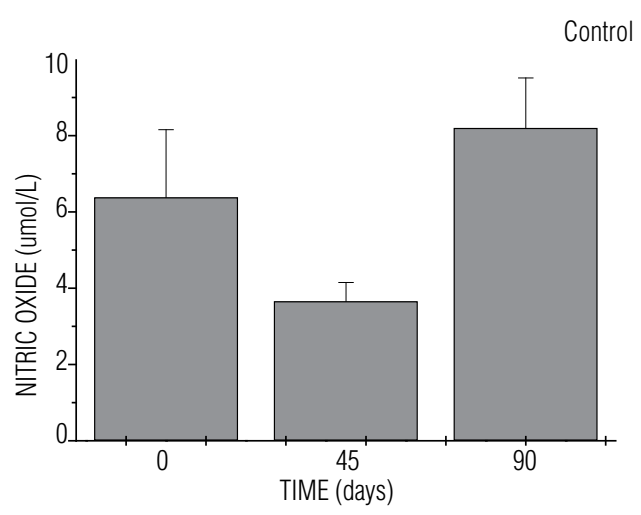

Fish Oil

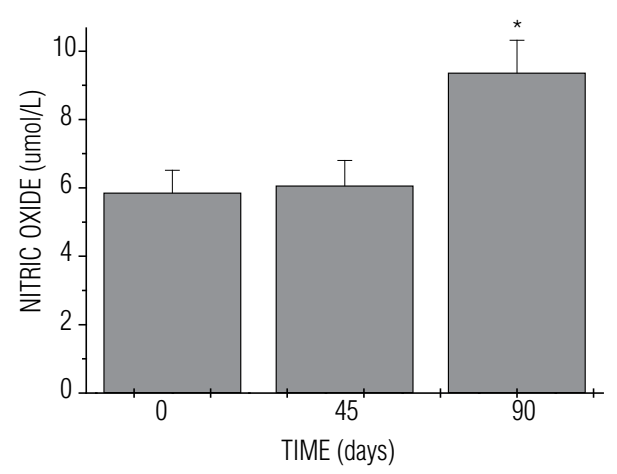

$(\mathrm{p}<0.05)$ (Table 4). NO metabolite levels showed significant increase $(\mathrm{p}<0.05)$ after 90 days in relation to baseline values, both in fish oil and soy groups, but this effect was not verified when fish oil and soy were given concomitantly (Figure 1).

\section{DISCUSSION}

To our knowledge, this is the first study to show the favorable effects of both fish oil and soy protein enriched with isoflavones on blood pressure and $\mathrm{NO}$ in patients with the MS, although a synergistic effect was not found. Of note, the effects of fish oil and soy protein on the parameters studied were not related to BMI, WC, and waist-to-hip ratio which remained practically unaltered throughout the research. The current study also showed, in accordance with the study of Sun and cols. (18), lower NO metabolite levels in patients with MS in relation to healthy controls.

Our findings of decreasing blood pressure with fish oil and soy protein enriched with isoflavones are in accordance with the literature. Soy protein had a sustained effect on diastolic blood pressure throughout all the study, whereas the effect of fish oil on systolic blood

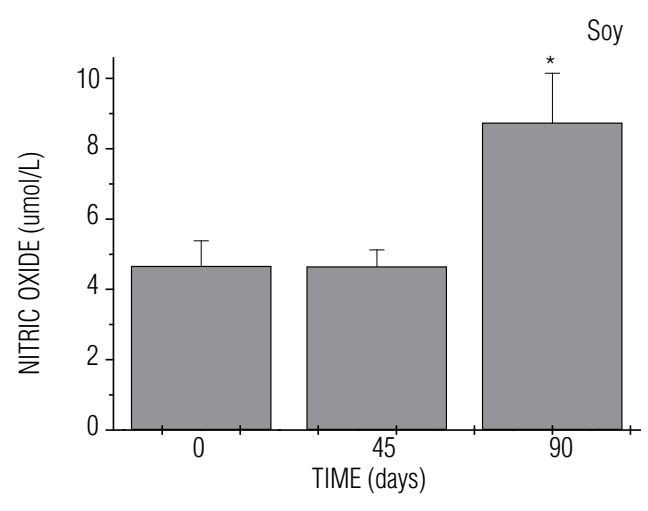

Fish Oil + Soy

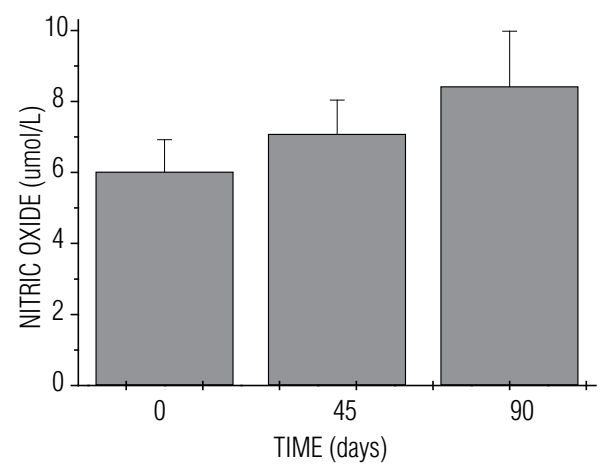

Figure 1. Nitric oxide metabolite levels in patients with the metabolic syndrome at baseline, and after 45 and 90 days of intervention. a) Control group; b) Soy group; c) Fish oil group; d) Group which associated the ingestion of soy and fish oil.

Within-group changes from baseline $(p<0.05)$. 
Table 4. Antropometric and blood pressure measurements in patients with the metabolic syndrome at baseline, and after 45 and 90 days of intervention

\begin{tabular}{lcccc}
\hline & $\begin{array}{c}\text { Group } \\
(\mathbf{n}=\mathbf{1 5})\end{array}$ & $\begin{array}{c}\text { Baseline } \\
(\mathbf{n = 1 5 )}\end{array}$ & $\begin{array}{c}\mathbf{4 5} \text { days } \\
\mathbf{( n = 1 5 )}\end{array}$ & $\begin{array}{c}\mathbf{9 0} \text { days } \\
\mathbf{( n = 1 5 )}\end{array}$ \\
\hline BMl & Control & $36.32(6.53)$ & $36.51(7.07)$ & $36.43(7.35)$ \\
$\left(\mathrm{kg} / \mathrm{m}^{2}\right)$ & Soy & $38.30(8.37)$ & $38.41(8.37)$ & $38.63(8.47)$ \\
& Fish oil & $34.34(7.21)$ & $33.90(7.59)$ & $35.31(8.84)$ \\
& Soy + Fish oil & $36.03(7.49)$ & $35.90(7.25)$ & $35.73(7.38)$ \\
WC (cm) & Control & $111.00(19.08)$ & $111.50(20.20)$ & $110.67(20.06)$ \\
& Soy & $115.50(15.30)$ & $113.79(14.77)$ & $113.57(14.11)$ \\
& Fish oil & $109.63(13.97)$ & $108.79(15.54)$ & $108.84(16.03)$ \\
& Soy + Fish oil & $117.08(27.07)$ & $117.54(29.76)$ & $118.38(29.56)$ \\
Waist-to- & Control & $0.92(0.08)$ & $0.92(0.08)$ & $0.91(0.08)$ \\
hip ratio & Soy & $0.95(0.05)$ & $0.95(0.05)$ & $0.95(0.05)$ \\
& Fish oil & $0.93(0.08)$ & $0.91(0.07)$ & $0.91(0.06)$ \\
& Soy + Fish oil & $0.93(0.05)$ & $0.94(0.09)$ & $0.97(0.11)$ \\
SBP & Control & $137.00(27.50)$ & $128.92(25.08)$ & $127.58(23.67)$ \\
(mmHg) & Soy & $135.79(14.19)$ & $128.79(13.06)$ & $132.43(14.25)$ \\
& Fish oil & $135.47(23.09)$ & $127.95(18.02)^{*}$ & $132.63(16.36)$ \\
& Soy + Fish oil & $136.69(17.58)$ & $133.54(15.64)$ & $127.77(13.34)$ \\
& Control & $87.33(18.86)$ & $80.25(13.25)$ & $89.25(15.57)$ \\
DBP & Soy & $91.00(11.80)$ & $83.00(13.74)^{*}$ & $80.07(10.46)^{*}$ \\
(mmHg) & Fish oil & $83.37(14.83)$ & $78.84(12.79)$ & $75.00(9.05)$ \\
& Soy + Fish oil & $83.62(9.70)$ & $81.54(8.05)$ & $83.23(9.20)$ \\
\hline & & & & \\
& & & & \\
& & &
\end{tabular}

Data are presented as mean \pm standard deviation.

BMI: body mass index; WC: waist circumference; SBP: systolic blood pressure; DBP: diastolic blood pressure.

* Within-group changes from baseline $(p<0.05)$.

pressure only occurred after 45 days. Soy protein intake has shown inverse association with blood pressure both in longitudinal studies (15) and in small-scale clinical trials with soy protein enriched with isoflavones (26-28). However, differently from our results, Azadbakht and cols. (12) using soy protein $(30 \mathrm{~g} / \mathrm{d})$ not enriched with isoflavones in MS patients did not show significant decrease in blood pressure. Several mechanisms can explain soy protein and isoflavones action on blood pressure: improvement in systemic arterial compliance (29), a natriuretic effect similar to furosemide (30), and amino acid composition (31). It can be hypothesized, in the current study, that insulin concentration decrease in patients with MS using soy protein enriched with isoflavones (data not shown) could lead to lower salt retention and therefore a reduced blood pressure, an underestimated mechanism for hypertension associated with insulin resistance (32).

Human studies have also shown that fish oil can lower blood pressure. A metaregression analysis of randomized trials verified that at doses between 3 and 5.6 $\mathrm{g} / \mathrm{d}$, fish oil reduced blood pressure in hypertensive individuals by up to $5.5 / 3.5 \mathrm{mmHg}$ (14). The mechanisms implicated include blunting of the synthesis of rennin-angiotensin-aldosterone system by decreasing adrenal synthesis of aldosterone (33), changes in renal arachdonic metabolism (33), blunting the sympathetic activity in adrenal response to mental stress with reduced cortisol release (34), and reducing heart rate (35).

Data on reduced blood pressure and NO increase in patients using fish oil or soy protein, shown in the present study, are in accordance with the literature. Both fish oil (36) and soy protein (37) could reduce blood pressure by stimulating $\mathrm{NO}$, a factor that is known to have vasodilatory effects (38). Fish oil action on NO may result from increased expression of endothelial nitric oxide synthase expression (eNOS) (39), whereas it can be hypothesized that the relative higher amount of NO precursor, arginine, in the amino acid profile of soy protein (40) could explain, at least in part, its effects on NO concentration, as the L-arginine/NO pathway plays a critical role in maintaining normal endothelial function by causing vasodilatation (41).

This study presents some limitations as there were a small number of subjects due to the difficulty in selecting patients who had the rigorous inclusion criteria adopted. Despite the measures taken to optimize compliance, it is difficult to assure that the individuals have fully abided by the instructions to consume soy and fish oil, and this issue could have interfered in the present results.

In conclusion, the finding of increased serum NO metabolite levels after 90 days both the in fish oil and soy protein groups of the current study reinforce the importance of the influence of NO levels on blood pressure in patients with the MS using fish oil or soy protein, although there were no significant differences in blood pressure and NO when fish oil and soy protein were associated. More human studies are warranted to confirm the relevant clinical results obtained in the present study.

Acknowledgments: we are grateful to National Council of Brazilian Research - CNPq, which supported this study, and to Good Soy Company for supplying the product kinako.

Disclosure: no potential conflict of interest relevant to this article was reported.

\section{REFERENCES}

1. Reaven GM. Role of insulin resistance in human disease. Diabetes. 1988;37:1595-607.

2. Ford ES, Giles WH, Mokdad AH. Increasing prevalence of the metabolic syndrome among U.S. adults. Diabetes Care. 2004;27:2444-9.

3. Barbosa PJB, Lessa I, Almeida-Filho N, Magalhães LBNC, Araújo J. Critério de obesidade central em população brasileira: impacto sobre a síndrome metabólica. Arq Bras Cardiol. 2006;87:407-14. 
4. Salaroli LB, Barbosa GC, Mill JG, Molina MC. Prevalence of metabolic syndrome in population-based study, Vitória, ES-Brazil. Arq Bras Endocrinol Metabol. 2007;51:1143-52.

5. Souza LJ, Gicovate Neto C, Chalita FEB, et al. Prevalência de obesidade e fatores de risco cardiovascular em Campos, Rio de Janeiro. Arq Bras Endocrinol Metab. 2003;47(6):669-76.

6. Oliveira EP, Souza MLA, Lima MDA. Prevalência de síndrome metabólica em uma área rural no semi-árido baiano. Arq Bras Endocrinol Metab. 2006;50(3):456-65.

7. Esmaillzadeh A, Kimiagar M, MehrabiY, Azadbakht L, Hu FB, Willet WC. Dietary patterns, insulin resistance, and prevalence of the metabolic syndrome in women. Am J Clin Nutr. 2007;85(3):910-8.

8. Jung UJ, Torrejon C, Tighe AP, Deckelbaum RJ. n-3 Fatty acids and cardiovascular disease: mechanisms underlying beneficial effects. Am J Clin Nutr. 2008;87(suppl):2003S-9S.

9. Calder PC. n-3 Polyunsaturated fatty acids, inflammation, and inflammatory diseases. Am J Clin Nutr. 2006;83(suppl):1505S-19S.

10. Deckelbaum RJ, Leaf A, Mozaffarian D, Jacobson TA, Harris WS, Akabas SR. Conclusions and recommendations from the symposium, beyond cholesterol: prevention and treatment of coronary heart disease with n-3 fatty acids. Am J Clin Nutr. 2008;87(suppl):2010S-2S.

11. Taku K, Umegaki K, Sato Y, Taki Y, Endoh K, Watanabe S. Soy isoflavones lower serum total and LDL cholesterol in humans: a meta-analysis of 11 randomized controlled trials. Am J Clin Nutr. 2007;85:1148-56.

12. Azadbakht $L$, Kimiagar $M$, Mehrabi $Y$, et al. Soy inclusion in the diet improves features of the metabolic syndrome: a randomized crossover study in postmenopausal women. Am J Clin Nutr. 2007; $85: 735-41$.

13. Reynolds K, Chin A, Lees KA, Nguyen A, Bujnowski D, He J. A meta-analysis of soy protein supplementation on serum lipids. Am J Cardiol. 2006;98:633-40.

14. Gelijnse JM, Giltay EJ, Grobbee DE, Donders AR, Kok FJ. Blood pressure response to fish oil supplementation: metaregression analysis of randomized trials. J Hypertens. 2002;20:1493-9.

15. Yang G, Shu X-O, Jin F, et al. Longitudinal study of soy intake and blood pressure among middle-aged and elderly Chinese women. Am J Clin Nutr. 2005;81:1012-7.

16. Hermann M, Flammer A, LüscherTF. Nitric oxide in hypertension. J Clin Hypertens. 2006;8(12 Suppl 4):17-29.

17. Woodman RJ, Mori TA, Burke V, et al. Effects of purified eicosapentaenoic and docosahexaenoic acids on glycemic control, blood pressure, and serum lipids in type 2 diabetic patients with treated hypertension. Am J Clin Nutr. 2002;76:1007-15.

18. Sun $Y X$, Hu SJ, Zhang $X H$, Sun J, Zhu CH, Zhang ZJ. Plasma levels of VWF and NO in patients with metabolic syndrome and their relationship with metabolic disorders. Zhejiang Da Xue Xue BaoYi Xue Ban. 2006;35:315-8.

19. AsI SZ, Ghasemi A, Azizi F. Serum nitric oxide metabolites in subjects with metabolic syndrome. Clin Biochem. 2008;41:1342-7.

20. Jacobs DR Jr. Executive summary of the third report of the National Cholesterol Education Program (NCEP) expert panel on detection, evaluation, and high blood cholesterol in adults (Adults Treatment Panel III). JAMA. 2001;285:2486-97.

21. Olsen SF, Osterdal ML, Salvig JD, et al. Fish oil intake compared with olive oil intake in late pregnancy and asthma in the offspring: 16 y of registry-based follow-up from a randomized controlled trial. Am J Clin Nutr. 2008;88:167-75.

22. Santana MB, Mandarino MG, Cardoso JR, et al. Association between soy and green tea (camellia sinensis) diminishes hypercholesterolemia and increases total plasmatic antioxidant potential in dyslipidemic subjects. Nutrition. 2008;24:562-8.
23. Pickering TG, Hall JE, Appel LJ, et al. Recommendations for blood pressure measurement in humans and experimental animals. Part 1: blood pressure measurement in humans: a statement for professionals from the Subcommittee of Professional and Public Education of the American Heart Association Council on High Blood Pressure Research. Hypertension 2005;45:142-61.

24. Guevara I, Iwanejko J, Dembinska-Kiéc A, et al. Determination of nitrito/nitrate in human biological material by the simple Griess reaction. Clin Chim Acta. 1998;274:177-88.

25. Gonzálvez JAN, Benayas CG, Arenas J. Semiautomated measurement of nitrate in bilogical fluids. Clin Chem. 1998;44:679-81.

26. Jenkins DJA, Kendall CWC, Jackson CJC, et al. Effects of highand low-isoflavone soyfoods on blood lipids, oxidized LDL, homocysteine, and blood pressure in hyperlipidemic men and women. Am J Clin Nutr. 2002;76:365-72.

27. He J, Gu D, Wu X, et al. Effect of soy bean protein on blood pressure: a randomized controlled trial. Arch Intern Med. 2005;143:1-9.

28. Burke V, Hodgson JM, Beilin LJ, Giangiulioi N, Rogers P, Puddey IB. Dietary protein and soluble fiber reduce ambulatory blood pressure in treated hypertensives. Hypertension. 2001;38:821-6.

29. Nestel P, Yamashita T, Sasahara T, et al. Soy isoflavones improve systemic arterial compliance but not plasma lipids in menopausal and perimenopausal women. Arterioscler Thromb Vasc Biol. 1997; 17:3392-8.

30. Gimenez I, Martinez RM, Lou M, Mayoral JA, Garay RP, Alda JO. Saliuretic action by genistein in the isolated, perfused rat kidney. Hypertension. 1998;31:706-11.

31. Carroll KK. Review of clinical studies on cholesterol-lowering response to soy protein. J Am Diet Assoc. 1991;91:82-7.

32. Sarafidis PA, Bakris GL. The antinatriuretic effect of insulin: an unappreciated mechanism for hypertension associated with insulin resistance? Am J Nephrol. 2007;27:44-54.

33. Engler MM, Engler MB, Goodfriend TL, et al. Docosahexaenoic acid is an antihypertensive nutrient that affects aldosterone production in SHR. Proc Soc Exp Biol Med. 1999;221:32-8.

34. Delarue J, Matzinger O, Binnert C, et al. Fish oil prevents the adrenal activation elicited by mental stress in healthy men. Diabetes Metab. 2003;29:289-95.

35. Mozaffarian D, Geelen A, Brouwer IA, Geleijnse JM, Zock PL, Ka$\tan$ MB. Effect of fish oil on heart rate in humans: a meta-analysis of randomized controlled trials. Circulation. 2005;112:1945-52.

36. Das UN. Beneficial effect(s) of n-3 fatty acids in cardiovascular diseases: but why and how? Prostaglandins Leukot Essent Fatty Acids. 2000;63:351-62.

37. Squandrito F, Altavilla D, Morabito N, et al. The effect of the phytoestrogen genistein on plasma nitric oxide concentrations, endothelin-1 levels and endothelium dependent vasodilatation in postmenopausal women. Atherosclerosis. 2002;163:339-47.

38. Smitzko PE, Wang CH, Weisel RD, de Almeida JR, Anderson TJ, Verma S. New markers of inflammation and endothelial cell activation: Part I. Circulation. 2003;108:1917-23.

39. Nyby MD, Abedi K, Eslami P, et al. Dietary fish oil prevents hypertension, oxidative stress and suppression of endothelial nitric oxide synthase expression in fructose-fed rats. Am J Hypertens. 2004;17:216A.

40. Erdman JW Jr. AHA Science Advisory: soy protein and cardiovascular disease: a statement for healthcare professionals from the Nutrition Committee on the AHA. Circulation. 2000;102:2555-9.

41. Bai $Y$, Lun S, Yang T, Sun K, Chen J, Hui R. Increase in fasting vascular endothelial function after short-term oral Larginine is effective when baseline flow-mediated dilatation is low: a meta-analysis of randomized trials. Am J Clin Nutr. 2009;89:77-84. 